\title{
MR neurography of a vagal neuropathy
}

\section{Figure 1 Magnetic resonance neurography and ultrasound findings in vagal neuropathy}

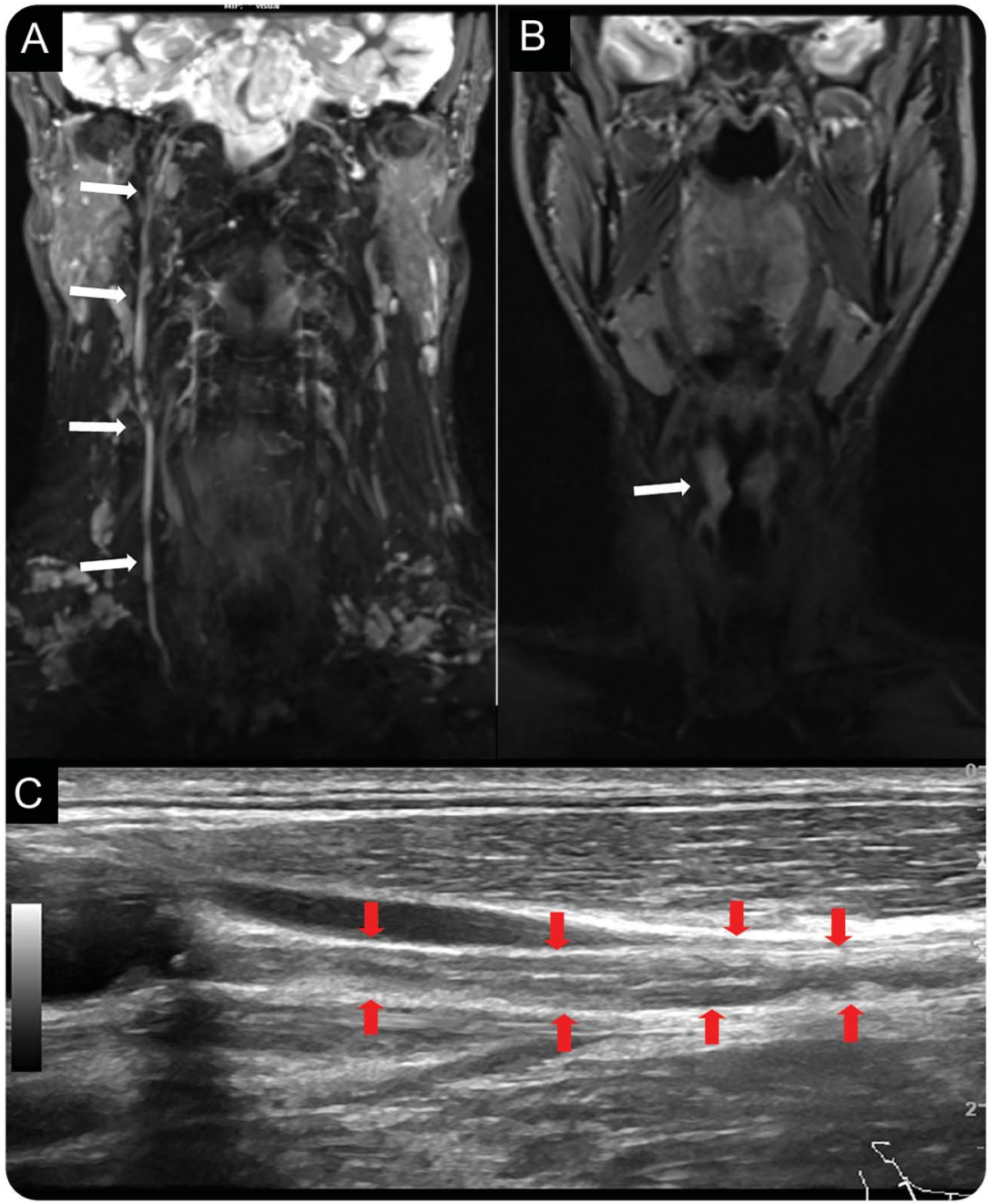

(A) Coronal subvolume MIP fat-suppressed T2-weighted magnetic resonance neurography image shows uniformly thickened and T2-hyperintense right vagus nerve (arrows). (B) Coronal fat-suppressed T2-weighted image of the larynx shows hyperintense signal of the right true vocal cord (arrow). Ultrasound longitudinal scan demonstrates thickening of right vagus nerve (arrows on C).

A 46-year-old man with a history of recurrent facial nerve palsies, right trigeminal neuralgia, and Horner syndrome presented with subacute onset of right laryngeal hemiparesis. CSF analysis revealed normal cell count and elevated protein level with albumin-cytologic dissociation. ${ }^{1}$ Imaging workup ruled out compressive and infiltrative causes. Magnetic resonance neurography (figures $1 \mathrm{~A}$ and 2, A-D) demonstrated uniform thickening, T2 signal hyperintensity, and contrast enhancement of the right vagal nerve, from skull base to the thyroid level. The right true vocal cord appeared adducted, T2 hyperintense, with contrast enhancement (figures 1B and 2, C-D), suggesting acute muscle denervation. ${ }^{2}$ A diagnosis of chronic inflammatory demyelinating cranial neuropathy was considered. 


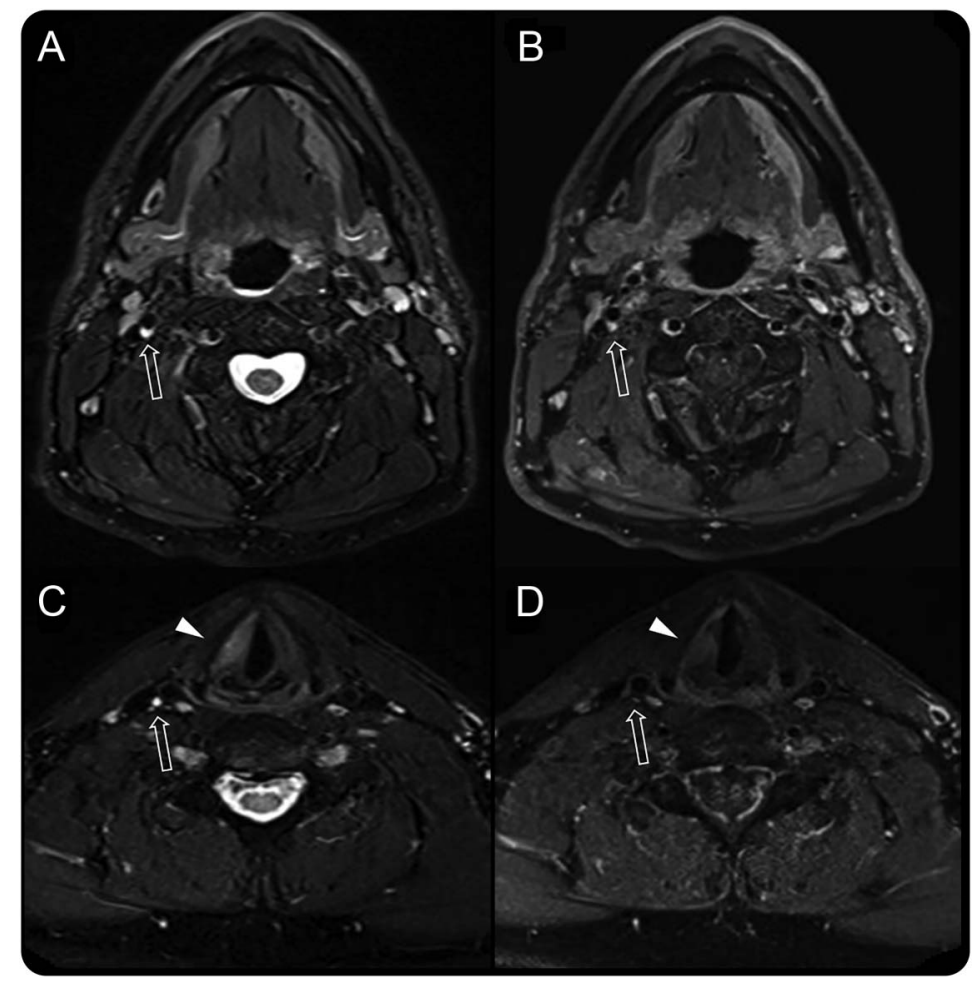

Axial fat-suppressed T2-weighted images $(A, C)$, with corresponding contrast-enhanced fat-suppressed T1-weighted images (B, D), show T2 hyperintensity and contrast enhancement of right vagus nerve (arrows, A-D) and of right true vocal cord (arrowheads, C and D). Vocal cord adduction, high T2 signal, and contrast enhancement (C and D) are consistent with palsy due to muscle denervation.

Elisa Ventura, MD, Concetta Manno, MD, Claudio Gobbi, MD, Valerio A. Vitale, MD,

Alessandro Cianfoni, $M D$

From the Neurocenter of Southern Switzerland, Regional Hospital of Lugano, Switzerland.

Author contributions: Dr. Ventura prepared the manuscript and the figure legends and collected the MRI. Dr. Manno provided the clinical data of the patient. Dr. Gobbi served as primary neurology consultant for the case. Dr. Vitale provided the ultrasound images. Dr. Cianfoni supervised the study concept and design and reviewed the manuscript and the image findings of the case.

Study funding: No targeted funding reported.

Disclosure: The authors report no disclosures relevant to the manuscript. Go to Neurology.org for full disclosures.

Correspondence to Dr. Ventura: elisa.ventura@eoc.ch

\section{REFERENCES}

1. Teramoto H, Morita A, Hara M, et al. Relapse with dysphagia in a case of chronic inflammatory demyelinating polyradiculoneuropathy. Intern Med 2015;54:1791-1793.

2. Kwong Y, Boddu S, Shah J. Radiology of vocal cord palsy. Clin Radiol 2012;67:1108-1114. 


\title{
Neurology
}

\author{
MR neurography of a vagal neuropathy \\ Elisa Ventura, Concetta Manno, Claudio Gobbi, et al. \\ Neurology 2016;87;234-235 \\ DOI 10.1212/WNL.0000000000002838
}

This information is current as of July 11, 2016

\section{Updated Information \& Services}

References

Permissions \& Licensing

Reprints including high resolution figures, can be found at: http://n.neurology.org/content/87/2/234.full

This article cites 2 articles, 0 of which you can access for free at: http://n.neurology.org/content/87/2/234.full\#ref-list-1

Information about reproducing this article in parts (figures,tables) or in its entirety can be found online at:

http://www.neurology.org/about/about_the_journal\#permissions

Information about ordering reprints can be found online:

http://n.neurology.org/subscribers/advertise

Neurology ${ }^{\circledR}$ is the official journal of the American Academy of Neurology. Published continuously since 1951, it is now a weekly with 48 issues per year. Copyright (O 2016 American Academy of Neurology. All rights reserved. Print ISSN: 0028-3878. Online ISSN: 1526-632X.

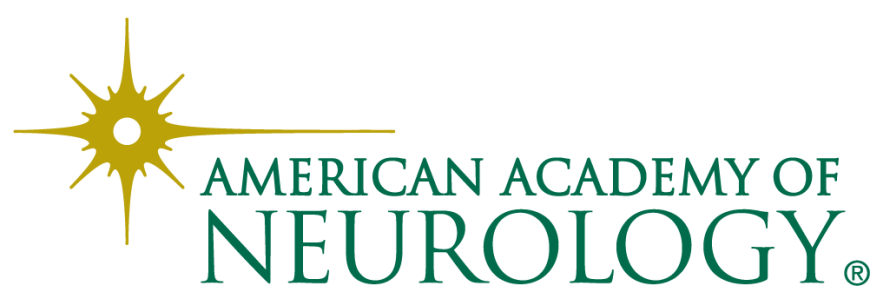

